\title{
ASSESSMENT OF ORTHODONTIC TREATMENT NEED AMONG TRIBAL CHILDREN OF INDORE DIVISION, CENTRAL INDIA
}

\author{
SHRIKANTH MURALIDHARAN ${ }^{1}$, ASTHA CHAUHAN ${ }^{2}$, \\ SRINIVASA GOWDA ${ }^{3}$, RUTUJA AMBEKAR ${ }^{4}$, BHUPENDRA S. RATHORE ${ }^{5}$, \\ SAKSHI CHABRA ${ }^{6}$, AFSHEEN LALANI ${ }^{7}$, HARSH HARANI ${ }^{8}$
}

\author{
${ }^{1}$ Department of Public Health Dentistry, MA Rangoonwala College of Dental \\ Sciences and Research Centre, Pune, India \\ ${ }^{2}$ Department of Public Health Dentistry, Index Institute of Dental Sciences, Indore \\ (M.P.), India \\ ${ }^{3}$ Department of Prosthodontics, MA Rangoonwala College of Dental Sciences and \\ Research Centre, Pune, India \\ ${ }^{4}$ Department of Orthodontics, MA Rangoonwala College of Dental Sciences and \\ Research Centre, Pune, India \\ ${ }^{5}$ Department of Orthodontics, College of Dental Sciences, Rau, (M.P.), India \\ ${ }^{6}$ Department of Public Health Dentistry, Pacific College of Dentistry, Udaipur, \\ Rajasthan, India \\ ${ }^{7}$ Department of Public Health Dentistry, Sri Aurobindo College of Dentistry, \\ Indore (M.P), India \\ ${ }^{8}$ Department of Orthodontics, Sri Aurobindo College of Dentistry, Indore (M.P), \\ India
}

Abstract

Introduction. India is home to many tribes which have an interesting and varied history of origins, customs and social practices. Oral health care in tribal areas is limited due to shortage of dental manpower, financial constraints and the lack of perceived need for dental care among tribal masses.

Objective. To assess orthodontic treatment need among tribal children of Indore division, Central India.

Methods. A cross-sectional house to house survey was carried out among 800 tribal children aged 5 to 15 years old in two major tribal districts of Indore division. Permissions and consent were obtained from local administrative authorities, ethical committee and parents respectively. A structured proforma was used to record demographic data. Examination for dentofacial anomalies was conducted according to WHO 1997 survey methods. Descriptive tables and analytical tests like ANOVA, post-hoc and chi-square test were employed.

Results. The mean age was 9.75( \pm 2.43$)$ years. The mean DAI score among 12 to 15

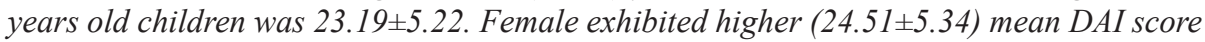
compared to males $(22.12 \pm 4.87)(p<0.05)$. The Patelia tribes $(24.38 \pm 5.13)$ reported higher mean DAI score than Bhilala (23.02 \pm 5.69$)$ and Bhil tribe $(22.73 \pm 4.79)(p<0.005)$.

Conclusion. The tribal children had minor malocclusion with no or slight treatment need. Categorization of orthodontic treatment need according to malocclusion severity is particularly important for the planning of corresponding public policies. The isolation of the villages, lack of transportation options imposes limitations on the availability of health professionals to provide dental services.

Keywords: tribal children, Indore division, orthodontic needs

Manuscript received: 18.03 .2017

Received in revised form: 12.05.2017

Accepted: 03.06.2017

Address for correspondence: dr.asthachauhan@gmail.com 


\section{Introduction}

A tribe is defined as a collection of families bearing a common name, speaking a common dialect, observing certain taboos regarding marriage, occupying or professing to a common territory and is not usually endogamous though originally it might have been so [1]. Despite remarkable world-wide progress in the field of diagnostics, curative and preventive health, still there are people living in isolation in the natural unpolluted surroundings far away from civilization. These people with their traditional values, customs, beliefs and myth intact are commonly known as "tribals" $[2,3,4]$. The largest tribal population resides in Madhya Pradesh i.e. Central India. Madhya Pradesh tribal group are mainly located in Northern and Eastern part of the state. These inhabitants are segregated from the modern civilization $[5,6,7]$. The health status of a society is intimately related to its value system, philosophical and cultural traditions, and social, economic and political organization. Each of these aspects has a deep influence on health, which in turn influences all these aspects [8]. Oral health is considered to be an essential part of general health and hence affects the total well- being of individuals [9].

Despite great success in improving the oral health of populations globally, problems still remain in many communities around the world, particularly among the under privileged groups in developing countries [2]. Due to their remote and isolated living, the tribal groups are difficult to reach $[8,10]$. It is reported that these tribal societies are very much ignorant about their oral health problems. The accessibility of these tribes to dental care is very minimal and neglected [2]. There is no means of oral health care to this civilization. The underlying cultural beliefs and practices influence the conditions of the teeth and mouth, through diet, care-seeking behaviors, or use of home remedies $[2,11,12]$.

Healthy mouth enables an individual to eat, speak and socialize without active disease or discomfort. It is concerned with maintaining the health of craniofacial complex, the teeth and gums as well as the tissue of the face and head that surrounds the mouth [13,14]. Dentofacial appearance has a lot to do with the way the people are perceived in the society [15]. Malocclusion is the second commonest dental anomaly. It may be handicapping to the functional needs and interfering with the well being of the person by adversely affecting dentofacial aesthetics, mandibular function or speech and Psychosocial health of an individual $[14,15]$. Hence, many indices have been developed with the intention of categorizing them into various groups according to severity of malocclusion [16] and need of the Orthodontic treatment so that individuals with greatest treatment need can be assigned priority when Orthodontic sources are limited. The WHO Oral Assessment form (1997) has been gaining international recognition as a method of objectively assessing dentofacial anomalies with other oral health status [17]. The demand for orthodontic treatment is increasing in most of the countries including India. Therefore, rational planning of orthodontic preventive measures on population basis is essential. Thus, the present study is an attempt to use WHO oral health assessment form as a comprehensive approach to allow selective distribution of resources so that the treatment could be provided at a high standard, and to protect children from the risks of unnecessary treatment within a finite framework [16]; thereby, benefitting local health authorities to plan their budget $[18,19]$.

\section{Materials and methods}

A cross-sectional study was carried out to assess the orthodontic treatment need among 5 - 15 year old tribal children over the period of six months. The study was conducted in Dhar and Jhabua districts of Indore division, Madhya Pradesh, Central India. The sample size of 800 was calculated based on pilot study using the G*Power 3 programme [20]. Three major tribes of the tribal communities were commonly found in this region namely Bhil, Bhilala, Patelia, which were assessed and compared. Ethical clearance was obtained from Institutional Review Board of Sri Aurobindo college of Dentistry, Indore. Permissions for conducting the study and clinical examinations on tribal children were obtained from administrative authorities of both the districts. Written Informed consent for participation was obtained from the parents or guardians of each child.

Inclusion criteria. The children aged 5 to 15 years permanently residing in the tribal villages of Indore division and never undergone any orthodontic treatment. Children who were voluntarily willing to participate.

Exclusion criteria. Previous orthodontic treatment or craniofacial malformations or syndromes with dentofacial manifestations. Children suffering from neurological or systemic diseases, acute pain or with any medically compromised condition that contra-indicates oral examination. Parents and children who did not provide consent for clinical examination.

\section{Pilot study}

A pilot study was carried out to check the feasibility and practicability of procedure of data collection before commencement of the main study. Pilot study was conducted among 30 tribal children aged 5 to 15 years. The pilot study samples were not included in the main study.

The examiner was calibrated and the intra-examiner reliability was found to be excellent $(\mathrm{kw}=0.82)$. Socio economic and demographic data were gathered by means of a proforma filled from the parents.

\section{Dental Aesthetic Index}

The normative criteria used to assess malocclusion prevalence and orthodontic treatment need was those from the Dental Aesthetic Index (DAI). The DAI is a normative instrument which is widely used in epidemiological studies to assess orthodontic treatment need [21]. This index assesses, in a single recording, physical and aesthetic 
features of the occlusion, defining, along its scale, the severity of malocclusion, in a way that approximates orthodontists' judgment. DAI scores equal to 25 or lower refer to normal occlusions, with little, if any, treatment need. Scores of 26 to 30 represent defined malocclusion, with elective treatment need. Scores of 31 to 35 represent malocclusion with high treatment need. Scores of 36 or higher represent more severe malocclusion, with obligatory treatment. The obtained values can thus be organized in a continuous scale from 13 to 80 or higher.

\section{Data collection}

Subjects were examined in the house-hold settings. Available infrastructure and furniture was utilized. Instrument and supplies were placed on the table within easy reach of examiner. The clinical examination involved an inspection of the oral cavity with plane mouth mirror and community periodontal (CPI) probe used for millimeter measurement under good illumination. ADA Type III examination was followed. The assessment of malocclusion was made according to the dental aesthetic index (DAI) as described by the WHO oral health survey, 1997. All the 10 components were measured.

\section{Statistical analysis}

The data collected was entered in Microsoft Excel and subjected to statistical analysis using Statistical Package for Social Sciences (SPSS, IBM version 20.0). The level of significance was fixed at $5 \%$ and $\mathrm{p} \leq 0.05$ was considered statistically significant. Descriptive statistics was used to find the frequencies, mean and standard deviation of variables considered in the study. The chi-square test was used to compare the categorical variables. Parametric tests like unpaired t-test and one way ANOVA test was performed for quantitative variables.

\section{Results}

The present study was carried out among 5 to 15 years old tribal children. The results are based on the data collected from 401 and 399 tribal children of Dhar and Jhabua districts of Indore division (M.P).

The frequency distribution of the study subjects according to their dentofacial anomalies such as crowding and spacing is shown in Table I. Crowding of teeth was significantly found among the 11 to 15 years old children on both the segments of dentition $(p<0.005)$. The two segments crowding was more commonly seen among the 15 years children $(62.7 \%)$ compared to 12 years children $(30.9 \%)$. Among the tribes, a significant difference was observed $(p<0.05)$. The Patelia tribe was experiencing significantly more crowding compared to other two tribes. In relation to their place of residence, Jhabua district exhibited more children with crowding compared to Dhar district $(\mathrm{p}<0.05)$. No significant difference in spacing between teeth was found among study subjects $(\mathrm{p}>0.05)$

The mean diastema of the total population of the present study was $0.07 \pm 0.24 \mathrm{~mm}$. The mean diastema $(\mathrm{mm})$ among the tribal children compared with respect to age, gender, tribes and location is shown in Figure 1. In WHO age group, 15 years old children $(0.11 \pm 0.32)$ showed higher mean diastema compared to 12 years old children $(0.08 \pm 0.24)$. Among the tribes, a significant difference was observed $(\mathrm{p}<0.05)$. A Tukey's post-hoc analysis indicated significant difference between Patelia tribe and Bhilala tribe $(\mathrm{p}<0.05)$. The Patelia tribe $(0.1 \pm 0.31)$ was experiencing significantly more diastema compared to Bhil $(0.07 \pm 0.24)$ and Bhilala $(0.05 \pm 0.19)$ tribes $(\mathrm{p}<0.05)$.

Table I. Comparison of crowding and spacing among tribal children with respect to Age, gender, tribe, location.

\begin{tabular}{|c|c|c|c|c|c|c|c|c|c|}
\hline \multicolumn{2}{|l|}{ Variables } & \multicolumn{3}{|l|}{ Crowding } & \multirow[b]{2}{*}{ Pvalue } & \multicolumn{3}{|l|}{ Spacing } & \multirow[b]{2}{*}{$P$ value } \\
\hline & & Absent & $\begin{array}{l}\text { One } \\
\text { segment }\end{array}$ & $\begin{array}{l}\text { Two } \\
\text { segment }\end{array}$ & & Absent & $\begin{array}{l}\text { One } \\
\text { segment }\end{array}$ & $\begin{array}{l}\text { Two } \\
\text { segmen }\end{array}$ & \\
\hline \multirow[t]{2}{*}{ Age group } & $5-10 Y$ & $232(72.9)$ & $52(16.4)$ & $34(10.7)$ & \multirow{2}{*}{$\begin{array}{l}0.00 \\
S\end{array}$} & $278(87.4)$ & $39(12.3)$ & $1(0.3)$ & \multirow{2}{*}{$\begin{array}{l}0.19 \\
\text { NS }\end{array}$} \\
\hline & $11-15 Y$ & $154(31.9)$ & $136(28.3)$ & $192(39.8)$ & & $439(91.1)$ & $41(8.5)$ & $2(0.4)$ & \\
\hline \multirow[t]{2}{*}{ WHO Age group } & 12 year & $42(33.3)$ & $45(35.7)$ & $39(30.9)$ & \multirow{2}{*}{$\begin{array}{l}0.00 \\
\mathrm{~S}\end{array}$} & $109(86.5)$ & $16(12.6)$ & $1(0.8)$ & \multirow{2}{*}{$\begin{array}{l}0.11 \\
\text { NS }\end{array}$} \\
\hline & 15 year & $16(21.3)$ & $12(16)$ & $47(62.7)$ & & $72(96)$ & $3(4)$ & $0(0)$ & \\
\hline \multirow[t]{2}{*}{ Gender } & Male & $231(51.3)$ & $110(24.4)$ & $109(24.2)$ & \multirow{2}{*}{$\begin{array}{l}0.08 \\
\text { NS }\end{array}$} & $403(89.5)$ & $45(10)$ & $2(0.4)$ & \multirow{2}{*}{$\begin{array}{l}0.95 \\
\text { NS }\end{array}$} \\
\hline & Female & $154(44)$ & $78(22.3)$ & $118(33.7)$ & & $313(89.4)$ & $35(10)$ & $1(0.3)$ & \\
\hline \multirow[t]{3}{*}{ Tribe } & Bhil & $193(51.3)$ & $81(21.5)$ & $102(27.1)$ & \multirow{3}{*}{$\begin{array}{l}\text { 0.01 } \\
\text { S }\end{array}$} & $334(88.8)$ & $40(10.6)$ & $2(0.5)$ & \multirow{3}{*}{$\begin{array}{l}0.68 \\
\mathrm{NS}\end{array}$} \\
\hline & Bhilala & $130(51.2)$ & $63(24.8)$ & $61(24)$ & & $233(91.7)$ & $21(8.3)$ & $0(0)$ & \\
\hline & Patelia & $62(36.5)$ & $44(25.9)$ & $64(37.6)$ & & $150(88.2)$ & $19(11.2)$ & $1(0.6)$ & \\
\hline \multirow[t]{2}{*}{ Location } & Dhar & $251(62.6)$ & $68(16.9)$ & $82(20.4)$ & \multirow{2}{*}{$\begin{array}{l}0.00 \\
\mathrm{~S}\end{array}$} & $364(90.8)$ & $35(8.7)$ & $2(0.5)$ & \multirow{2}{*}{$\begin{array}{l}0.42 \\
\text { NS }\end{array}$} \\
\hline & Jhabua & $134(33.6)$ & $120(30.1)$ & $145(36.3)$ & & $353(88.5)$ & $45(11.3)$ & $1(0.2)$ & \\
\hline \multicolumn{2}{|c|}{ Total study population } & $384(48)$ & $188(23.5)$ & $226(28.2)$ & & $717(89.6)$ & $80(10)$ & $3(0.4)$ & \\
\hline
\end{tabular}


Figure 1. Comparison of mean diastema (mm) among study population with respect to age, gender, tribe and location.

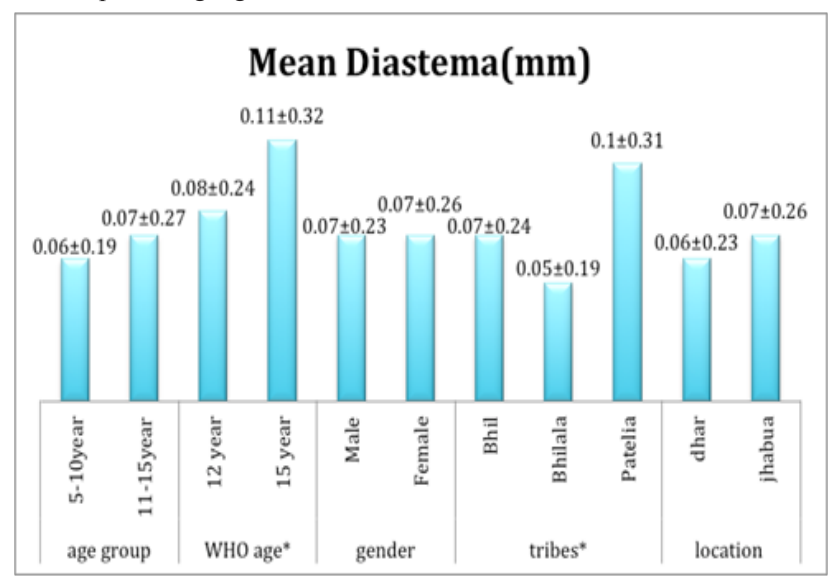

Statistical test employed: Independent sample t test, one-way ANOVA $S=$ Significant $(p<0.05)$

$(N S)=$ non significant $(p>0.05)$

The mean largest anterior maxillary irregularity of the total population of the present study was of $0.67 \pm 1.27$ $\mathrm{mm}$. The mean of largest anterior maxillary irregularities in millimeter was compared among study population with respect to age, gender, tribe and location shown in Figure 2. Children belonging to 11 to 15 years of age had $(1.05 \pm 1.51)$ more anterior maxillary irregularities compared to younger age group of 5 to 10 years $(0.09 \pm 0.27)(\mathrm{p}<0.05)$. In WHO age group 15 years age children were $1.25 \pm 1.58$ were having more irregularities compared to 12 year age $(0.59 \pm 1.20)$ $(\mathrm{p}<0.05)$. Statistically no significant gender, tribes, location variation was observed with largest anterior maxillary irregularities. $(\mathrm{p}>0.05)$

The mean largest anterior mandibular irregularity of the total population of the present study was of $0.94 \pm 1.4$ $\mathrm{mm}$. The mean of largest anterior mandibular irregularities was compared among study population with respect to age, gender, tribe and location shown in Figure 3. A statistically significant difference in anterior mandibular irregularities was observed. Children belonging to 11 to 15 years age group had $(1.42 \pm 1.61)$ more anterior mandibular irregularities compared to younger age group $(0.23 \pm 0.43)(\mathrm{p}<0.05)$. In WHO age group 15 years age children had $(1.49 \pm 1.63)$ more irregularities compared to 12 year age $(0.88 \pm 1.34)(\mathrm{p}<0.05)$. Females $(1.17 \pm 1.55)$ exhibited more anterior mandibular irregularities compared to males $(0.77 \pm 1.25) \quad(p<0.05)$. In terms of place of residence, children residing in Jhabua district (1.25 \pm 1.57$)$ reported more largest anterior mandibular irregularities compared to Dhar district $(0.64 \pm 1.13)(\mathrm{p}<0.05)$.

The frequency distribution of the study subjects according to their dento-facial anomalies such as anteroposterior molar relation is shown in Table II. Statistically no significant age and gender variation was observed with dentofacial anomalies. In WHO age children, 12 years showed significantly more number of malocclusion compared to 15 years $(\mathrm{p}<0.05)$. In terms of tribes, Bhilala tribes exhibited more cases of malocclusion compared to Bhil and Patelia tribes $(p<0.05)$. In relation to their place of residence, Dhar district reported more children with half cusp compared to Jhabua district $(\mathrm{p}<0.05)$.

Figure 2. Comparison of mean of largest anterior maxillary irregularities $(\mathrm{mm})$ among study population with respect to age, gender, tribe and location.

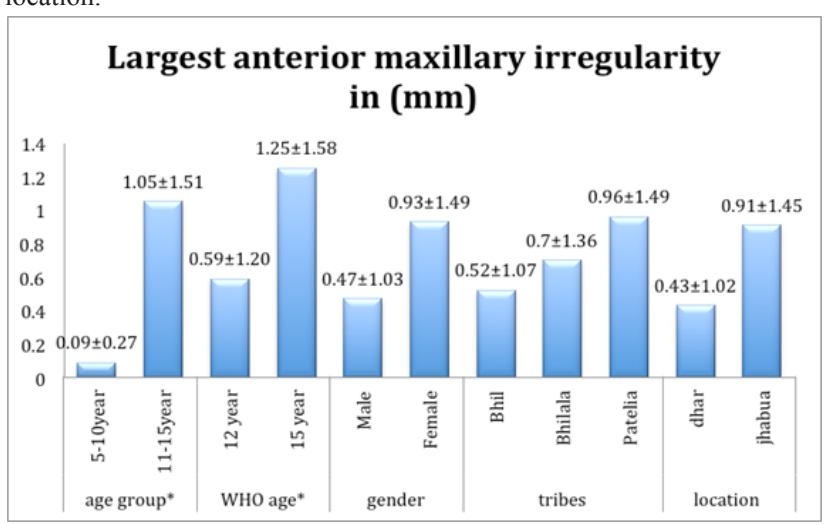

Statistical test employed: Independent sample t test, one-way ANOVA $S=$ Significant $(p<0.05) \quad(N S)=$ non significant $(p>0.05)$

Figure 3. Comparison of mean of largest anterior mandibular irregularities $(\mathrm{mm})$ among study population with respect to age, gender, tribe and location.

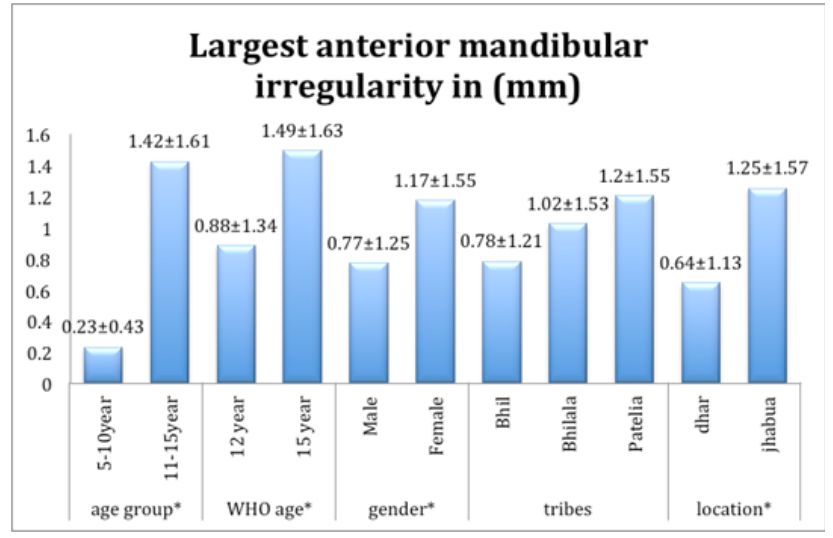

Statistical test employed: Independent sample t test, one-way ANOVA $S=$ Significant $(p<0.05)$

$(N S)=$ non significant $(p>0.05)$

Figure 4. Comparison of anterior maxillary over-jet with respect to age, gender, tribe and location.

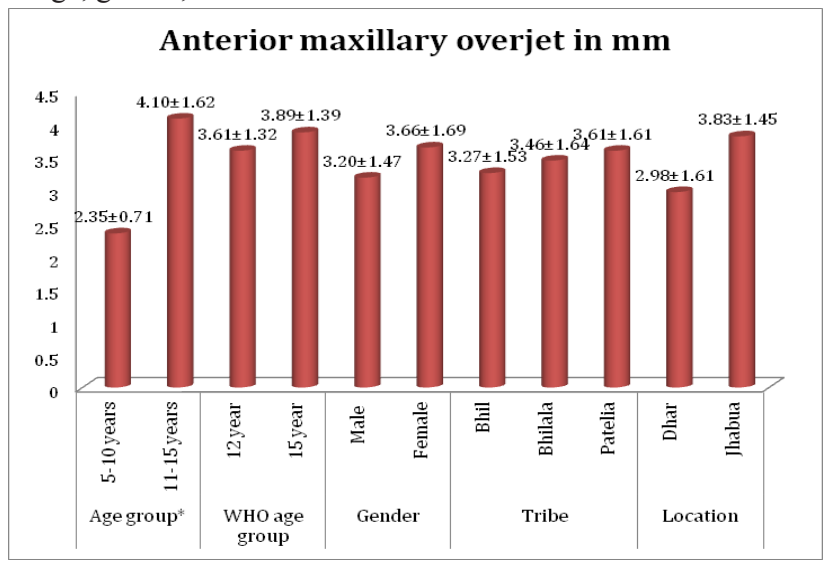

Statistical test employed: Independent sample t test, one-way ANOVA $S=$ Significant $(p<0.05)$ $(N S)=$ non significant $(p>0.05)$ 
The mean anterior maxillary over-jet of the total population of the present study was of $3.51 \pm 1.59 \mathrm{~mm}$. The anterior maxillary over-jet was compared among the age-group, gender and tribe in Figure 4. A statistically significant increased over-jet of $4.1 \pm 1.62 \mathrm{~mm}$ was observed in children aged 11 to 15 years compared to younger aged children. There was no significant variation found among the gender, tribe and place of residence $(\mathrm{p}>0.05)$

Table III shows the mean DAI score of study subjects aged 12 to 15 years. The mean DAI score among
12 to 15 years old children was $23.19 \pm 5.22$. In WHO age groups, the mean DAI score is significantly higher in 15 years $(24.16 \pm 5.11)$ compared to 12 years of age $(22.4 \pm 5.0)$ $(\mathrm{p}<0.05)$. Female exhibited higher $(24.51 \pm 5.34)$ mean DAI score compared to males $(22.12 \pm 4.87)(\mathrm{p}<0.05)$. The Patelia tribes $(24.38 \pm 5.13)$ reported higher mean DAI score than Bhilala $(23.02 \pm 5.69)$ and Bhil tribe $(22.73 \pm 4.79)$ $(\mathrm{p}<0.005)$. A Tukey's post-hoc analysis indicated a significant difference between Patelia tribe and Bhil tribe $(\mathrm{p}<0.05)$.

Table II. Comparison of antero-posterior molar relation among study population with respect to age, gender, tribe and location.

\begin{tabular}{|c|c|c|c|c|c|c|c|c|}
\hline \multirow{2}{*}{\multicolumn{2}{|c|}{ Variables }} & \multicolumn{6}{|c|}{ A-P Molar relation } & \multirow{4}{*}{\begin{tabular}{|l|} 
P value \\
0.145 \\
NS
\end{tabular}} \\
\hline & & \multicolumn{2}{|c|}{ Half cusp } & \multicolumn{2}{|c|}{ Normal } & \multicolumn{2}{|c|}{ Full cusp } & \\
\hline \multirow[t]{2}{*}{ Age group } & 5-10 years & 12 & $(3.8)$ & 304 & $(95.6)$ & 2 & $(0.6)$ & \\
\hline & 11-15 years & 8 & $(1.6)$ & 470 & $(97.5)$ & 4 & $(0.9)$ & \\
\hline \multirow[t]{2}{*}{ WHO age group } & 12 year & 2 & $(1.5)$ & 123 & $(97.6)$ & 1 & $(0.8)$ & \multirow{2}{*}{$\begin{array}{l}0.002 \\
\text { S }\end{array}$} \\
\hline & 15 year & 0 & $(0.0)$ & 75 & $(100)$ & 0 & $(0.0)$ & \\
\hline \multirow[t]{2}{*}{ Gender } & Male & 15 & $(3.4)$ & 433 & $(96.2)$ & 3 & $(0.4)$ & \multirow{2}{*}{$\begin{array}{l}0.552 \\
\mathrm{NS}\end{array}$} \\
\hline & Female & 5 & $(1.4)$ & 343 & $(98.0)$ & 3 & $(0.6)$ & \\
\hline \multirow[t]{3}{*}{ Tribe } & Bhil & 6 & $(1.6)$ & 370 & $(98.4)$ & 1 & $(0.0)$ & \multirow{3}{*}{$\begin{array}{l}0.008 \\
\text { S }\end{array}$} \\
\hline & Bhilala & 11 & $(4.3)$ & 239 & $(94.1)$ & 4 & $(1.6)$ & \\
\hline & Patelia & 3 & $(1.8)$ & 167 & $(98.2)$ & 1 & $(0.0)$ & \\
\hline \multirow[t]{2}{*}{ Location } & Dhar & 18 & $(4.5)$ & 383 & $(95.5)$ & 0 & $(0.0)$ & \multirow{2}{*}{$\begin{array}{l}0.000 \\
\text { S }\end{array}$} \\
\hline & Jhabua & 2 & $(0.5)$ & 393 & $(98.5)$ & 6 & $(1.5)$ & \\
\hline \multicolumn{2}{|c|}{ Total study population } & 20 & $(2.5)$ & 774 & $(96.7)$ & 6 & $(0.75)$ & \\
\hline
\end{tabular}

Table III. Comparison of mean dental aesthetic index (DAI) score among tribal children aged 12 to 15 years with respect to age, gender, tribes.

\begin{tabular}{|c|c|c|c|c|}
\hline \multicolumn{2}{|l|}{ Variables } & \multicolumn{2}{|c|}{ DAI score } & \multirow[t]{2}{*}{ P value } \\
\hline & & Mean & S.D & \\
\hline Age group & $12-15$ years & 23.19 & 5.22 & - \\
\hline \multirow[t]{2}{*}{ WHO Age group } & 12 years & 22.4 & 5.0 & \multirow{2}{*}{$\begin{array}{l}0.021 \\
(S)\end{array}$} \\
\hline & 15 years & 24.16 & 5.11 & \\
\hline \multirow[t]{2}{*}{ Gender } & Male & 22.12 & 4.87 & \multirow{2}{*}{$\begin{array}{l}0.000 \\
(S)\end{array}$} \\
\hline & Female & 24.51 & 5.34 & \\
\hline \multirow[t]{3}{*}{ Tribe } & Bhil & 22.73 & 4.79 & \multirow{3}{*}{$\begin{array}{l}\mathbf{0 . 0 5 0} \\
(\mathrm{S})\end{array}$} \\
\hline & Bhilala & 23.02 & 5.69 & \\
\hline & Patelia & 24.38 & 5.13 & \\
\hline \multicolumn{2}{|c|}{ Total study population } & 23.20 & 5.22 & \\
\hline
\end{tabular}

Statistical test employed: Independent sample T test, one way ANOVA
$(\mathrm{S})=$ Significant $(\mathrm{p}<0.05)$
$(N S)=$ Non-significant $(p>0.05)$

\# Tukey's Post-hoc analysis comparing the DAI score among different tribes of study population.

\begin{tabular}{|l|l|l|l|}
\hline Tribe & Bhil & Bhilala & Patelia \\
\hline Bhil & - & $.876(\mathrm{NS})$ & $\mathbf{. 0 4 3 *}(\mathbf{S})$ \\
\hline Bhilala & $.876(\mathrm{NS})$ & - & $.142(\mathrm{NS})$ \\
\hline Patelia & $\mathbf{. 0 4 3 *}(\mathrm{S})$ & $.142(\mathrm{NS})$ & - \\
\hline
\end{tabular}




\section{Discussion}

In this study the need for orthodontic treatment was assessed in $5-15$ years old children coming from tribal areas of central India and, therefore, they are those who would benefit the most from a public dental health program. Although the sample was only representative for this population, the study can provide an overview about the orthodontic treatment needs of the local children in this age group.

There are malocclusions defined as being harmful to oral health according to Dental Health Component, although no aesthetic impairment is involved, such as crossbite or absence of posterior teeth, nonerupted or impacted canines and premolars $[22,23,24]$. On the other hand, there are cases defined only by Aesthetic Component as being of great treatment need because certain malocclusions considered to produce unattractive aesthetics are not evaluated by Dental Health Component (e.g. anterior spacing) [22,24]. As Aesthetic Component is more subjective, it also brings difficulties in assessing some parameters, such as degrees of overjet and overbite [25,26,27].

The dentofacial anomalies evaluated using Dental Aesthetic Index indicated a mean DAI score of 23.19 \pm 5.22 . The tribal children had minor malocclusion with no or slight treatment need. This can be attributed to presence of other anomalies along with ideal class I molar relationship like presence of supernumerary teeth, spacing, peg lateral, cross bite. Similar findings were reported by Bhat M [28] studying a rural Indian fishing community; Wyk PJV and Pretoria CVW [29] studying school children in South Africa.; Garner LD and Butt MH [30] on back Americans and Nyeri Kenyans and Grewe JM et al. [31], on Chippewa Indian children. However, fact that the female gender is more likely to have a definite need of orthodontic treatment was an interesting finding. This could be due to the desire to look better and more attractive. Since then, other studies $[32,33]$ found no statistically significant difference regarding the gender distribution. Indication for early treatment of some malocclusions cited above emphasizes the importance of evaluating children with primary, mixed dentition and permanent dentition.

Among the malocclusions found, crowding in one or more segments was the most frequent type, with followed by Class I molar relationship and horizontal maxillary over jet equal to $4 \mathrm{~mm}$ or greater, which was observed among tribal children. Because of the aesthetic relevance of these malocclusions, they have received high social value [34,35] and it is an important reason for demanding orthodontic treatment [36].

Although crowding has been the most frequently reported malocclusion. Our results $(51.75 \%)$ were higher than those reported by Dias and Gleiser [37] (45.5\%), Sousa et al. [38] (28.3\%) and Marques [39] (37.8\%), among others, and lower to those reported by Freitas et al. [40] (69\%) and Lopes and Gangussu [41] (65\%).
The overall factors such as anthropologic, social or environmental, crowding could be due to a discrepancy that arises when the tooth size is relatively too big for the given arch circumference or due to the age range assessed. It can be partially explained by the great incidence of carious lesions and extractions of deciduous molars, which favors migration of the first permanent molars as well as inclinations and rotations. Several studies investigated wider age ranges, with inclusion of subjects with mixed dentition. This fact was observed by Sousa et al. [38], who found increased crowding rates during the transition from deciduous to mixed and permanent dentitions.

The same variability may be observed for the molar relationship and maxillary overjet. While Lopes and Gangussu [41] reported a similar prevalence rate of Class I molar relationship in the $12-15$ years age range, Almeida et al [42] found a prevalence rate of $48 \%$, that was closer to our results. The largest discrepancy among the study measures, however, was related to maxillary overjet. In relation to increased overjet, the most severe cases should be treated early in order to prevent dental traumas and to improve lip function, breathing, and self-esteem.[43,44] Our result is consistent with those reported by Marques et al [39] and Cavalcanti et al. [45]. and contrary to studies reported by Dias and Gleiser [37] (29.7\%) and Lopes and Gangussu [41] who found a prevalence rate of malocclusion over $90 \%$ in their samples.

The wide variability of malocclusion prevalence rates is mainly due to the different methods and indices used. Furthermore, differences among the age ranges studied may also have contributed to the variability of the reported results. Categorization of orthodontic treatment need according to malocclusion severity is particularly important for the planning of corresponding public policies.

Orthodontic treatment may thus be associated with cultural trends and social status [46] which may subjectively foster an increased perception of orthodontic treatment need, through and additional effect of the desire to undergo such treatment. The isolation of the villages, lack of transportation options imposes limitations on the availability of health professionals to provide dental services.

In the present study, however, the normative evaluation based on the Dental Aesthetic Index may not be enough because of the often inherent elective nature of this treatment. As a result, other factors such as perceptual, functional and social needs may interfere with treatment demand and service planning $[32,33,47,48]$ since those factors do not always coincide with the professional evaluation of treatment need. [49] Therefore, further studies investigating the patient's perception and his or her concern regarding orthodontic treatment should be carried out in order to enhance the DAI efficacy. The results of the present study can be carefully generalized to other population of similar rural and backward communities. 


\section{Conclusion}

This is a descriptive cross sectional study. Oral health is negligible in tribal parts of the country. And if we talk about orthodontic treatment it is far from the imagination of people living in such places. As we all know, Orthodontic problems lead to many other oral health problems. To date, no such study took place in this area to find out about the basic orthodontic conditions of such area. So, this study provides the gist of today's orthodontic condition of tribal children of central India showing minor or no orthodontic treatment need but other anomalies such as overjet or crowding prevailed in this community. This study is an eye opener for the administrative and public health experts to give emphasis on the minor orthodontic correction and its awareness which can further lead to many oral health problems.

\section{Acknowledgements}

Author would like to thank all the administration for providing details of tribes and tribal children and all the participants and their parents for participating in the study.

\section{References}

1. Viragi PS, Dwijendra KS, Kathariya MD, Chopra K, Dapde MV, Madhukar HS. Dental health and treatment needs among children in a tribal community. J Contemp Dent Pract. 2013;14(4):747750 .

2. Vivek S, Jain J, Simon SP, Battur H, Tikare S, Mahuli A. Understanding oral health beliefs and behavior among Paniyan tribals in Kerala, India. Journal of International Oral Health. 2012;4(2):23-28.

3. Narayan DD, Dhondibarao GR, Ghanshyam KC. Prevalence of tobacco consumption among the adolescents of the tribal areas in Maharashtra. Journal of Clinical and Diagnostic Research. 2011;5(5):1060-1063.

4. Kumar TS, Dagli RJ, Mathur A, Jain M, Balasubramanyam G, Prabu D, Kulkarni S. Oral health status and practices of dentate Bhil adult tribe of southern Rajasthan, India. Int Dent J. 2009;59:133-140.

5. Pandey GD. A study of demographic characteristics of tribals in rural Madhya Pradesh. Some observations for health and family welfare planning. Indian Journal of Preventive and Social Medicine. 1988;19(4):119-138.

6. Primitive tribes of Madhya Pradesh. Tribal Research and Development Institute, Bhopal: 2013.

7. Pandey GD, Tiwari RS. Socio-cultural reproductive health practices of primitive tribes of Madhya Pradesh: Some observations. J Family Welfare. 2001;47(2):27-33.

8. Basu S. Dimensions of tribal health in India. Health and Population- Perspectives and Issues 2000;23(2):61-70.

9. Sogi GM, Bhaskar DJ. Dental caries and oral hygiene status of school children in Davangere related to their socio-economic levels: an epidemiological study. J Indian Soc Pedod Prev Dent. 2002;20(4):152-157.

10. Mathur JN. Health status of primitive tribes of Orissa. Indian Council of Medical Research Bulletin, New Delhi. 2003;33(10):1-54. 11. Health of Tribal Population in India; Results of Some ICMR Studies. Indian Council of Medical Research, New Delhi, page no.1, 1998.

12. Butani Y, Weintraub JA, Barker JC. Oral health-related cultural beliefs for four racial/ethnic groups: Assessment of the literature. BMC Oral Health. 2008 Sep 15;8:26. doi: 10.1186/1472-68318-26.

13. Dunning JM. Principles of Dental Public Health, 4th ed, Cambridge Harvard University Press, 1986.

14. Yewe Dyer M. The definition of oral health. Br Dent J. 1993;174:224-225.

15. Samire B. Text book of orthodontics, Harcourt (India) Pvt. Ltd: Philadelphia W.B. Saunders; 2001: 460-476.

16. de Oliveira CM. The planning, contracting and monitoring of orthodontic services, and the use of the IOTN index: a survey of consultants in dental public health in the United Kingdom. $\mathrm{Br}$ Dent J. 2003;195(12):704-706.

17. World Health Organization. Oral Health Surveys, Basic methods, 4th ed, Geneva: WHO; 1997.

18. Bernabé E, Flores-Mir C. Orthodontic treatment need in Peruvian young adults evaluated through dental aesthetic index. Angle Orthod. 2006;76:417-421.

19. Sachdeva A, Raghav S, Baheti K, Ali MJ, Goel M. Assessment of Orthodontic Treatment Needs Among School Going Children Using Index of Orthodontic Treatment Need (IOTN) in Indore (Central India), Madhya Pradesh, India. EC Dental Science. 2016;4(6):908-918.

20. Faul F, Erdfelder E, Lang AG, Buchner A. G*Power 3: a flexible statistical power analysis program for the social, behavioral, and biomedical sciences. Behav Res Methods. 2007;39:175-191.

21. de Almeida AB, Leite IC. Orthodontic treatment need for Brazilian schoolchildren: a study using the Dental Aesthetic Index. Dental Press J Orthod. 2013;18(1):103-109.

22. Crowther P, Harkness M, Herbison P. Orthodontic treatment need in 10-year-old Dunedin schoolchildren. $N$ Z Dent J. 1997;93(413):72-78.

23. Mandall NA, Wright J, Conboy F, Kay E, Harvey L, O'Brien $\mathrm{KD}$. Index of orthodontic treatment need as a predictor of orthodontic treatment uptake. Am J Orthod Dentofacial Orthop. 2005;128(6):703-707.

24. Burden DJ, Holmes A. The need for orthodontic treatment in the child population of the United Kingdom. Eur J Orthod. 1994;16(5):395-399.

25. Burden DJ, Pine CM, Burnside G. Modified IOTN: an orthodontic treatment need index for use in oral health surveys. Community Dent Oral Epidemiol. 2001;29(3):220-225.

26. Dean JA, McDonald SM, Walker PO. Public assistance orthodontic treatment needs: a report from the state of Indiana. J Public Health Dent. 2005;65(3):133-137.

27. Dias PF, Gleiser R. Orthodontic treatment need in a group of 9-12-year-old Brazilian schoolchildren. Braz Oral Res. 2009;23(2):182-189.

28. Meghashyam B, Nagesh L, Ankola A. Dental caries status and treatment needs of children of fisher folk communities, residing in the coastal areas of Karnataka region, south India. West Indian Med J. 2007;56(1):96-98.

29. van Wyk PJ, van Wyk C. Oral health in South Africa. Int Dent J. 2004;54(6 Suppl 1):373-377.

30. Garner LD, Butt MH. Malocclusion in back Americans and Nyeri Kenyans. An epidemiologic study. Angle Orthod. 1985;55:139-146.

31. Grewe JM, Cervenka J, Shapiro BL, Witkop CJ Jr. Prevalence of malocclusion in Chippewa Indian children. J Dent Res. 
1968;47(2):302-305.

32. Üçüncü N, Ertugay E. The use of the Index of Orthodontic Treatment need (IOTN) in a school population and referred population. J Orthod. 2001;28(1):45-52.

33. Chew MT, Aw AK. Appropriateness of orthodontic referrals: self-perceived and normative treatment needs of patients referred for orthodontic consultation. Community Dent Oral Epidemiol. 2002;30(6):449-454.

34. Shaw WC. The influence of children's dentofacial appearance on their social attractiveness as judged by peers and lay adults. Am J Orthod. 1981;79(4):399-415.

35. Shaw WC, Rees G, Dawe M, Charles CR. The influence of dentofacial appearance on the social attractiveness of young adults. Am J Orthod. 1985;87(1):21-26.

36. Kilpeläinen PV, Phillips C, Tulloch JF. Anterior tooth position and motivation for early treatment. Angle Orthod. 1993 Fall;63(3):171-174.

37. Dias PF, Gleiser R. Orthodontic treatment need in a group of 9-12-year-old Brazilian schoolchildren. Braz Oral Res. 2009;23(2):182-189.

38. Sousa RLS, Lima RB, Florencio C Filho, Lima KC, Diogenes AMN. Prevalencia e fatores de risco da mordida aberta anterior na dentadura decidua complete em pre-escoalres na cidade de Natal - RN. Rev Dental Press Ortod Ortop Facial. 2007;12(2):129-138. 39. Marques LS, Barbosa CC, Ramos-Jorge ML, Pordeus IA, Paiva SM. Prevalencia da ma oclusao e necessidade de tratamento ortodontico em escolares de 10 a 14 anos de idade de Belo Horizonte, Minas Gerais, Brasil: enfoque psicossocial. Cad Saude Publica. 2005;21(4):1099-106.

40. Freitas MR, Freitas DS, Pinheiro FHS, Freitas, KMS. Prevalencia das mas oclusoes em pacientes inscritos para tratamento ortodontico na Faculdade de Odontologia de Bauru-
USP. Rev Fac Odontologia Bauru. 2002;10(3):164-169.

41. Lopes LS, Cangussu MCT. Prevalencia e severidade das alteracoes oclusais em escolares de 12 a 15 anos de Salvador BA, 2004. Rev Cienc Med Biol. 2005;4(2):105-112.

42. Almeida MEC, Vedovello Filho M, Vedovello SAS, Lucatto A, Torrezan AT. Prevalencia da ma oclusao em escolares da rede estadual do municipio de Manaus, AM - Brasil. RGO: Rev Gauch Odontol. 2007;55(4):389-394.

43. Tausche E, Luck O, Harzer W. Prevalence of malocclusions in the early mixed dentition and orthodontic treatment need. Eur J Orthod. 2004;26(3):237-244.

44. Kluemper GT, Beeman CS, Hicks EP. Early orthodontic treatment: what are the imperatives? J Am Dent Assoc. 2000;131(5):613-620.

45. Cavalcanti AL, Bezerra PKM, Alencar CRB, Moura C. Prevalencia de Maloclusao em escolares de 6 a 12 anos de idade em Campina Grande, PB, Brasil. Pesq Bras Odontoped Clin Integr. 2008;8(1):99-104.

46. Baldwin DC. Appearance and aesthetics in oral health. Community Dent Oral Epidemiol. 1980;8(5):244-256.

47. Mugonzibwa EA, Kuijpers-Jagtman AM, van 't Hof MA, Kikwilu EN. Demand for orthodontic treatment among 9-18 yearolds seeking dental care in Dar-es-Salaam, Tanzania. East Afr Med J. 2004;81(1):3-9.

48. Hamdan AM. The relationship between patient, parent and clinician perceived need and normative orthodontic treatment need. Eur J Orthod. 2004;26(3):265-271.

49. Shue-Te Yeh M, Koochek AR, Vlaskalic V, Boyd R, Richmond S. The relationship of 2 professional occlusal indexes with patients' perceptions of aesthetics, function, speech, and orthodontic treatment need. Am J Orthod Dentofacial Orthop. 2000;118(4):421-428. 